\title{
Criteria of Cure and Remission in Cushing's Disease: An Update
}

revisão

\author{
Mauro A. CZeplelewski \\ GUILHERME A.F.S. ROLIIN \\ ALESSANDRA CASAGRANDE \\ NELSON P. FERREIRA
}

Division of Endocrinology, Hospital de Clínicas de Porto Alegre, e Programa de

Pós-Graduação em Ciências Médicas - Endocrinologia,

Faculdade de Medicina, UFRGS, Porto Alegre, RS.
Recebido em 24/10/07 Aceito em 30/10/07

\begin{abstract}
We review the clinical and biochemical criteria used for evaluation of the transsphenoidal pituitary surgery results in the treatment of Cushing's disease (CD). Firstly, we discuss the pathophysiology of the hypothalamic-pituitary-adrenal axis in normal subjects and patients with $C D$. Considering the series published in the last 25 years, we observed a significant variation in the remission or cure criteria, including the choice of biochemical tests, timing, threshold values to define remission, and the interference of glucocorticoid replacement or previous treatment. In this context we emphasize serum cortisol levels obtained early (from hours to 12 days) in the postoperative period without any glucocorticoid replacement or treatment. Our experience demonstrates that: (i) early cortisol $<5$ to $7 \mu \mathrm{g} / \mathrm{dl}$, (ii) a period of glucocorticoid dependence $>6 \mathrm{mo}$, (iii) absence of response of cortisol/ACTH to CRH or DDAVP, (iv) return of dexamethasone suppression, and circadian rhythm of cortisol are appropriate indices of remission of $C D$. In patients with undetectable cortisol levels early after surgery, recurrence seems to be low. Finally, although certain biochemical patterns are more suggestive of remission or surgical failure, none has been proven to be completely accurate, with recurrence observed in approximately 10 to $15 \%$ of the patients in long-term follow-up. We recommended that patients with CD should have long-term monitoring of the $\mathrm{CRH}-\mathrm{ACTH}$-cortisol axis and associated co-morbidities, especially hypopituitarism, diabetes mellitus, hypertension, cardiovascular disturbances, and osteoporosis. (Arq Bras Endocrinol Metab 2007;51/8:1362-1372)
\end{abstract}

Keywords: Cushing's disease; Transsphenoidal surgery; Remission criteria; Post-operative evaluation in Cushing's disease; Cortisol; ACTH; DDAVP; CRH

\section{RESUMO}

Critérios de Cura e Remissão na Doença de Cushing: Uma Atualização.

Neste artigo, são revisados os principais critérios clínicos e hormonais utilizados para avaliação do tratamento cirúrgico da Doença de Cushing (DC). Inicialmente são comentados aspectos fisiopatológicos que orientam a avaliação hormonal e os principais fatores clínicos, laboratoriais, cirúrgicos e histológicos associados com melhores resultados, observados nas principais séries da literatura e em pacientes acompanhados prospectivamente pelos autores. Foram revisados, também, critérios adotados nas principais séries da literatura, nos últimos 25 anos, chamando-se atenção para as dosagens hormonais, o momento em que foram realizadas, a possibilidade de interferência de tratamentos prévios e da reposição glicocorticóide. À seguir, essas dosagens são discutidas salientando-se a importância do cortisol obtido seqüencialmente no pós-operatório e sem a interferência de reposição glicocorticóide. A experiência prospectiva dos autores, recentemente referendada na literatura, demonstra que valores de cortisol $<5$ a $7 \mu \mathrm{g} / \mathrm{dl}$ associados com um período de dependência aos glicocorticóides $>6$ meses, ausência de resposta do $\mathrm{ACTH} /$ cortisol ao DDAVP e/ou $\mathrm{CRH}$, retorno da supressão à dexametasona e do ritmo circadiano, estão associados com remissão da DC. Em pacientes com cortisol indetectável após cirurgia transesfenoidal, a chance de recidiva parece ser menor do que naqueles em que se observa cortisol detectável. Finalmente, chamamos a atenção para que, mesmo adotando critérios rígidos de avaliação, a recidiva da DC pode ocorrer a longo prazo em até $15 \%$ dos casos, recomendando-se, portanto, que esses pacientes sejam acompanhados por tempo indeterminado, com monitorização cuidadosa do eixo CRH-ACTH-cortisol e de suas co-morbidades, especialmente hipopituitarismo, diabete melito, hipertensão arterial, alterações cardiovasculares e osteoporose. (Arq Bras Endocrinol Metab 2007;51/8:1362-1372)

Descritores: Doença de Cushing; Cirurgia transesfenoidal; Critérios de cura; Avaliação pós-operatória da doença de Cushing; Cortisol; ACTH; DDAVP; $\mathrm{CRH}$ 
$\mathrm{C}$ USHING'S DisEASE (CD) is a weakening illness caused by adrenal steroids excess, especially cortisol, due to ACTH hormone-secreting pituitary adenoma. Usually they are microadenomas $(90 \%)(<1 \mathrm{~cm}$ in diameter), and the treatment of choice is currently transsphenoidal pituitary surgery (TSS). Radiation therapy, bilateral adrenalectomy, and medical treatment, that inhibits adrenal steroid synthesis or antagonize its effects, are considered alternative or secondline treatment. Due to the relative rarity of the condition (incidence is estimated at $0.7-2.4$ cases $/ \mathrm{mil}$ lion/yr), only few medical centers have enough experience to establish evidence-based diagnostic and therapeutic protocols (1-6).

Moreover, due to the high morbidity and mortality rates, it demands an effective treatment with prompt results and long-term remission. In this setting, safe criteria should be essential to define CD cure or remission but several questions are still to be answered (5-10).

Here we review our current understanding about CD remission and suggest a postoperative diagnostic approach based in our experience in management of 108 patients with CD.

\section{PATHOPHYSIOLOGY OF HYPOTHALAMIC-PITUITARY-ADRENAL AXIS IN CUSHING'S DISEASE}

Firstly, it is important to analyze the pathophysiology of the hypothalamic-pituitary-adrenal (HPA) axis in Cushing's disease. Figure 1 shows the hormonal pattern observed in CD, before (figure 1A) and immediately after TSS in cured (figure ID), not cured patients (figure $1 \mathrm{C}$ ), and in patients with slow decrease of cortisol probably harboring adrenal nodular bilateral hyperplasia (figure 1B). As observed, pituitary adenoma secretes large amounts of ACTH in serum, which in turn stimulates cortisol secretion that, through negative feedback, suppresses endogenous CRH and ACTH secretion. Immediately after successful surgical procedure, there will be a transitory hypocortisolism period due to secondary or tertiary suppression of CRH-ACTH-cortisol normal axis (figure 1D) (11). Some patients with $\mathrm{CD}$, especially those with bilateral macronodular adrenal hyperplasia caused by chronic ACTH hypersecretion, can present, even after complete tumor removal, some autonomous adrenal secretion of cortisol (figure $1 \mathrm{~B}$ ) (12). In those cases we could not observe an abrupt decrease of cortisol levels after TSS. Similarly, this situation can be seen in patients with persistent adenoma, in whom some ACTH-cortisol secretion remains without adrenal hypocortisolism (figure 1C).

Subjects with normal pituitary function secrete large amounts of ACTH and cortisol when submitted to surgical and anesthetic procedures, demonstrated by Udelsmann et al. (13). Similar pattern was described in patients with acromegaly and non-functioning pituitary adenomas (14). These findings suggest that in the postoperative period of CD pituitary surgery, an initial increase in ACTH and cortisol levels could be seen due to anesthetic and surgical stress, together with post-surgical hormonal alterations. Conversely, hypocortisolism after complete resection of the tumor associated with concomitant damage to normal corticotroph cell function is another pattern after surgery. Then, the HPA axis dynamics in normal subjects and in CD patients submitted to TSS showed many alterations. These hormonal profiles offer many possibilities and questions about the evaluation of these patients including: what is the best moment to reevaluate, which hormonal test could be more useful, what is the interference of exogenous glucocorticoid replacement, and which criteria should be adopted to better indicate cure or remission $(1,5-7,10,15-18)$.

\section{FACTORS ASSOCIATED TO CURE OR REMISSION RATES IN CUSHING'S DISEASE}

Besides acceptable biochemical criteria to evaluate CD treatment outcome, there are many other factors that could predict remission (table 1). Initially, we should consider disease characteristics and determine its aggression. Most patients present histological adenoma patterns characterized by sparsely or dense pitu-

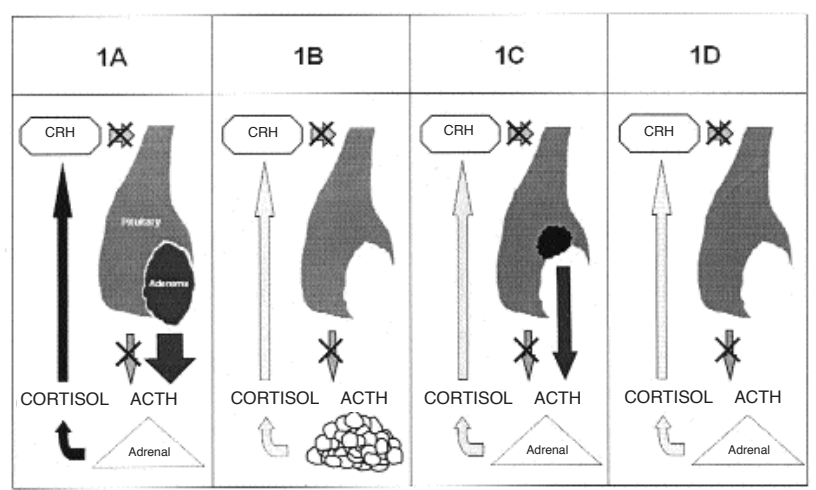

Figure 1. Schematic representation of the pathophysiology of the hypothalamic-pituitary-adrenal axis in patients with Cushing's disease: pre-treatment $(1 \mathrm{~A})$, in patient with remission and reduction of cortisol and adrenal hyperplasia (1B), with residual adenoma (1C) and in patient with remission (1D). 
Table 1. Features associated with $C D$ remission.

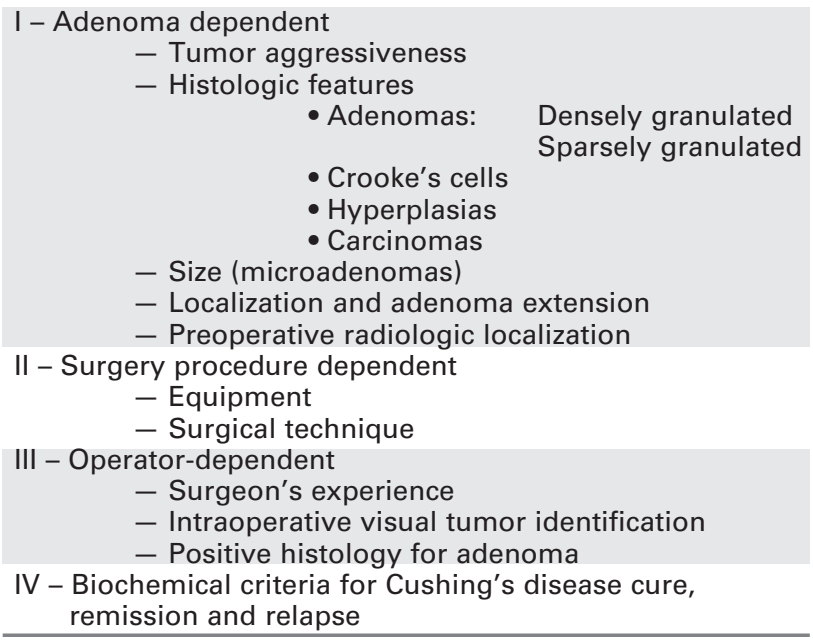

itary adenoma and more rarely with Crooke's cells adenoma. As suggested by George et al., Crooke's cells adenoma are more aggressive tumors, most are macroadenomas at the diagnosis and are associated with poorer outcome (19). Large pituitary tumor and invasiveness of adjacent structures are associated with poor therapeutic results too $(1,6,20-23,26)$. Patients who showed a significant gradient between the pituitary (central) and peripheral ACTH values in the inferior petrosal sinus sampling present better prognosis (27). Some studies describe the presence of major aggressiveness in male subjects, resulting in worse surgical results $(6,28)$. Indeed, tumor localization, especially superior growth and intermediary pituitary lobe involvement, are also associated with worse prognosis $(1,6)$. Technical surgical procedures and disposal equipment to better visualize the tumor also play an important role in successful outcome. In practice, TSS pituitary tumor resection experience is based on classical microscopic approach. Although endoscope surgery is less aggressive to bone structures and propose more post-surgical comfort to the patient, there is not enough experience to compare both procedures $(29,31)$.

Among experienced neurosurgeons, cure rate in the first surgery in CD is about 83 to $91 \%$ in microadenomas and 25 to $73 \%$ in macroadenomas $(1,2,6,10,22,31,32)$. Tumor identification in the surgery together with histological adenoma confirmation are associated with better results $(1,30,31)$. Guilhaume et al. showed that patients with histological adenoma confirmation have better remission rates than those with negative histology ( $72 \%$ vs. $24 \%$ ) (30). In our series (table 2), we observed that patients not cured by surgery had higher body weigh, bigger tumor
Table 2. Features associated to remission in 72 patients with Cushing's disease.

\begin{tabular}{lccc}
\hline & $\begin{array}{c}\text { Remission } \\
(\#)\end{array}$ & $\begin{array}{c}\text { No-remission } \\
(\#)\end{array}$ & p \\
Gender (F/M) & $36 / 14$ & $6 / 2$ & \\
Weight/BMI & $75.8 \pm 16$ & $98.6 \pm 24.4$ & $<0.05$ \\
Age (years) & $34.5 \pm 7$ & $38.4 \pm 8$ & $\mathrm{~ns}$ \\
Time of disease & $3.39 \pm 2.43$ & $3.56 \pm 2.58$ & $\mathrm{~ns}$ \\
(years) & & & \\
Macro (\%) & $7 / 47(15 \%)$ & $4 / 9(44 \%)$ & 0.04 \\
Cortisol 8 hs $\left(^{*}\right)$ & $26.7 \pm 8.16$ & $34 \pm 9.4$ & $\mathrm{~ns}$ \\
UFC $(\mu \mathrm{g} / 24 \mathrm{hs})$ & $415 \pm 413$ & $463 \pm 276$ & $\mathrm{~ns}$ \\
Cort-24hs $\left(^{*}\right)$ & $24 \pm 11.2$ & $30 \pm 9.6$ & $\mathrm{~ns}$ \\
Cort-1 mg $\left(^{*}\right)$ & $15.9 \pm 8.4$ & $21.7 \pm 11.4$ & $\mathrm{~ns}$ \\
Cort-2 mg $\left(^{*}\right)$ & $16.7 \pm 16.3$ & $19.7 \pm 9.9$ & $\mathrm{~ns}$ \\
SDHEA $(*)$ & $266 \pm 200$ & $453 \pm 305$ & $<0.05$ \\
ACTH Basal $\left(^{* *}\right)$ & $56 \pm 34.3$ & $62.4 \pm 10$ & $\mathrm{~ns}$ \\
\hline
\end{tabular}

$\#$ = values expressed by mean \pm standard deviation (except gender)

UFC: urinary free cortisol, Cort-24 hs: midnight serum cortisol, Cort-1 mg: serum cortisol level after $1 \mathrm{mg}$ dexamethasone, Cort-2 mg: serum cortisol after 2 mg dexamethasone, ns: not significant

* $\mathrm{mcg} / \mathrm{dl} ;{ }^{* *} \mathrm{pg} / \mathrm{ml}$

size, and higher SDHEA serum levels $(\mathrm{p}<0.05)$. We did not observe significant difference in characteristics such as gender, age, disease duration, basal cortisol and ACTH levels, midnight plasma cortisol, 24-hr urinary cortisol, and low-dose dexamethasone suppression test.

Indeed, surgical results are dependent on assumed cure criteria. Less strict criteria could result in higher rates of cure. Even adopting more stringent criteria, recurrence occurs in 5 to $15 \%$ of cases $(1,25,33$ $35,38-40)$. In cured patients, glucocorticoid replacement therapy is mandatory during HPA recover. This time is approximately 11 to 14 months $(1,6,10,11$, $17,18,26,41)$. CD in children seems to be more aggressive, with less cure rates (long term remission of $53 \%)$ and more relapses $(6,42)$. At this age additional factors that contribute to worse outcomes are a higher incidence of small tumors and the lack of complete development of sphenoidal sinus (42).

\section{CLINICAL FEATURES}

Although biochemical tests are relevant markers to evaluate CD surgery outcome, cured subjects also present improvement of clinical features. Significant changes correspond to body weight reduction, changes in body composition, osteoporosis overcome, better muscle strength, disappearance or improvement of metabolic disturbance such as diabetes and hypertension. These clinical improvements are very important to the patien- 
t's quality of life, once it represents the return to normal activities. Some studies suggest that even cured patients might continue to have a poor quality of life (43-46). Possible explanations for this observation are the definitive systemic damage caused by $\mathrm{CD}$ or are associated to the poor biochemical criteria adopted. In children, normal growth and puberty development are the best clinical criteria to evaluate CD cure.

\section{CURE OR REMISSION CRITERIA}

Before the introduction of hormonal measurement, in the sixties, the cure or remission of $\mathrm{CD}$ was based on disappearance of clinical signs and symptoms. After that, disease status could be evaluated based on urinary adrenal hormone metabolites, such as 17-hidroxy- and 17-ketosteroides in 24 hs urine sample. Advances in biochemical tests, especially after the introduction of radioimmunoassay (RIE) to measure cortisol and ACTH levels and the spread of RIE, made it possible to establish disease activity based on hormonal plasma levels.

Table 3 summarizes the cure/remission criteria used in main expert centers in CD treatment. Notably, the criteria for remission vary significantly in the studies from the last 25 years and could not define a single gold standard test that could accurately evaluate disease status. Table 4 lists biochemical tests that have been examined for their usefulness in predicting relapse.

\section{HORMONAL REMISSION OR CURE CRITERIA}

\section{Serum cortisol}

Postoperative serum cortisol is the major marker used to evaluate CD activity $(25,26,33,34,36,47)$. Ideal time for serum collection does not follow any standard pattern and presents a wide variation between different centers (table 3). Measurement of cortisol just after surgery has always been difficult because former recommendation on the use of glucocorticoid to prevent adrenal insufficiency interfered with endogenous cortisol levels. This procedure, although recommended by some centers, has never been confirmed by prospective studies. In 2001, Simmons et al. showed the first series where glucocorticoid was not used during TSS. Subsequently, they measured serum cortisol for 3 days, four times a day (47). They observed that successful approach was associated with cortisol levels less than $275.9 \mathrm{nmol} / \mathrm{L}$. Based on this study and in HPA pathophysiology in CD, we propose that cortisol levels must be measured in a serial pat- tern during immediate post-surgical procedure and subsequently in 6,12 , and 24 hours. This practice must be interrupted when clinical signs of hypocortisolism occurred, or when cortisol levels fall to less than $5 \mu \mathrm{g} / \mathrm{dl}$. In a period of 10 to 12 days after TSS procedure, if the subject is on glucocorticoid reposition, this should be stopped and basal plasma cortisol and cortisol in 24-h urine collection should be taken. In 2004, applying the above proposal in more than 100 patients with $\mathrm{CD}$, we showed that serum cortisol less than 5 to $7 \mu \mathrm{g} / \mathrm{dl}$ defines cure with sensitivity and specificity of around of $100 \%$ (26). Our findings, similarly to those of Esposito et al. (48), verify that cortisol levels less than $140 \mathrm{nmol} / \mathrm{L}$ in the first and second days after surgery were associated with CD resolution. Recently, Acebes et al. (36) observed that cortisol levels more than $585 \mathrm{nmol} / \mathrm{L} 24$ $\mathrm{h}$ post-surgery indicates disease persistence.

In 1993, Toms and cols. reported 11 patients with histologically confirmed adenoma in which cortisol levels were measured at $9 \mathrm{~h}$, between 5 to 14 days; and 6 to 12 weeks after TSS (49). They received oral hydrocortisone until $18 \mathrm{~h}$ the day before blood collection. Follow-up consisted of periodic cortisol measurement after overnight dexamethasone test. From this group, 4 patients presented recurrence of the disease 2 to 48 months after surgery and the other 7 patients remained free of disease. Cortisol levels less than $35 \mathrm{nmol} / \mathrm{L}$ discriminated those with long-term remission, whereas cortisol values were lower during 6-12 weeks than 2 weeks after surgery. In a study by Pereira et al. (25) six patients with normal serum cortisol in the first several weeks after surgery developed late hypocortisolism. Five of these patients had macroadenomas and none had relapse in 4-years average follow up. These data suggest that in some patients successful adenoma resection is associated with gradual resolution of adrenal autonomy, especially when the adrenal glands show significant bilateral hyperplasia. Moreover, gradual decline in cortisol during early postoperative period would be related to delayed adenoma necrosis.

Many authors consider that $\mathrm{CD}$ remission is associated with cortisol levels less than $7 \mu \mathrm{g} / \mathrm{dl}(15),<550$ $\mathrm{nmol} / \mathrm{L}(50)$ during the first days after surgery, although the majority considers values such as $<50 \mathrm{nmol} / \mathrm{L} \mathrm{(33}$, $34,39,40)$. In patients taking glucocorticoid, it is necessary to withdraw it few hours before cortisol collection.

The postoperative hypoadrenalism, characterized by undetectable cortisol levels, is associated with lower risk of relapse but this is not absolute. Moreover, several studies have showed recurrence of hypercortisolism after a period of adrenal insufficiency $(26,35,39)$. 
Czepielewski et al.

Table 3. Hormonal criteria for Cushing's disease remission (*).

\begin{tabular}{|c|c|c|c|}
\hline Author, year & Timing of Postoperative Testing & Biochemical testing & Remission cutoff value \\
\hline Hardy, 1982 & ND & $\begin{array}{l}\text { Cortisol } \\
\text { Urinary } 17-\mathrm{OHCS} \\
\text { or UFC }\end{array}$ & $\begin{array}{l}\text { Normal } \\
\text { Normal } \\
\text { Normal }\end{array}$ \\
\hline Boggan, 1983 & 6 wk & $\begin{array}{l}\text { ACTH } \\
\text { Cortisol } \\
\text { LD-DST }\end{array}$ & $\begin{array}{l}\text { Normal } \\
\text { Normal } \\
\text { Normal }\end{array}$ \\
\hline Fahlbusch, 1986 & $5-6 d$ & $\begin{array}{l}\text { LD-DST }(2 / 3 \mathrm{mg}) \text { or } \\
\text { Adrenal insuficiency }\end{array}$ & $<2 \mu \mathrm{ND} / \mathrm{dL}$ \\
\hline Chandler, 1987 & within $1 \mathrm{wk}$ & $\begin{array}{l}\text { Cortisol } \\
\text { UFC }\end{array}$ & $\begin{array}{l}<20.5 \mu \mathrm{g} / \mathrm{dL} \\
<130 \mu \mathrm{g} / \mathrm{dL}\end{array}$ \\
\hline Nakane, 1987 & ND & $\begin{array}{l}\text { Cortisol } \\
\text { ACTH }\end{array}$ & $\begin{array}{l}<20 \mu \mathrm{g} / \mathrm{dL} \\
<100 \mathrm{pg} / \mathrm{mL}\end{array}$ \\
\hline Schrell, 1987 & $7-10 d$ & $\begin{array}{c}\text { ACTH (am) } \\
\text { Cortisol (am) } \\
\text { LD-DST }(2 \mathrm{mg})\end{array}$ & $\begin{array}{c}<50 \mathrm{pg} / \mathrm{mL} \\
<21 \mu \mathrm{g} / \mathrm{dL} \\
\text { NI suppression }\end{array}$ \\
\hline Guilhaume, 1988 & $3-6 \mathrm{mo}$ & $\begin{array}{l}\text { UFC } \\
8 \mathrm{pm} \text { cortisol }\end{array}$ & $\begin{array}{l}<90 \mu \mathrm{g} / \mathrm{d} \\
<100 \mathrm{ng} / \mathrm{mL}\end{array}$ \\
\hline Mampalam, 1988 & ND & $\begin{array}{l}\text { Cortisol } \\
\text { ACTH } \\
\text { LD-DST }\end{array}$ & $\begin{array}{l}\text { Normal } \\
\text { Normal } \\
\text { NI supression }\end{array}$ \\
\hline Pieters, 1989 & $1 \mathrm{~d}$ & AM cortisol & $<7 \mu \mathrm{g} / \mathrm{dL}$ \\
\hline Arnott, 1990 & $1-4$ wk & UFC & $<490 \mathrm{nmol} / \mathrm{d}$ \\
\hline Burke, 1990 & $4 \mathrm{wk}$ & $\begin{array}{c}\text { UFC } \\
12 \text { am cortisol }\end{array}$ & $\begin{array}{l}<280 \mathrm{nmol} / \mathrm{d} \\
<280 \mathrm{nmol} / \mathrm{L}\end{array}$ \\
\hline Tindall, 1990 & $1-24 \mathrm{wk}$ & $\begin{array}{l}\text { Cortisol } \\
\text { UFC }\end{array}$ & $\begin{array}{l}\text { Normal } \\
\text { Normal }\end{array}$ \\
\hline Ludecke, 1991 & $16 \mathrm{~h}$ & $\begin{array}{c}\text { Cortisol } \\
\text { ACTH }\end{array}$ & $\begin{array}{l}\text { Subnormal } \\
\text { Subnormal }\end{array}$ \\
\hline Lindholm, 1992 & ND & $\begin{array}{c}\text { UFC or } \\
\text { Cortisol after ACTH Stimulation }\end{array}$ & $\begin{array}{l}235 \mathrm{nmol} / \mathrm{d} \\
\text { Low }\end{array}$ \\
\hline McCance, 1993 & $1-14 d$ & $\begin{array}{l}\text { AM cortisol } \\
\text { LD-DST }(2 \mathrm{mg}) \\
\text { UFC }\end{array}$ & $\begin{array}{l}<550 \mathrm{nmol} / \mathrm{L} \\
<60 \mathrm{nmol} / \mathrm{L} \\
<330 \mathrm{nmol} / \mathrm{d}\end{array}$ \\
\hline Trainer, 1993 & $1 \mathrm{~d}$ & AM cortisol & $<50 \mathrm{nmol} / \mathrm{L}$ \\
\hline Ram, 1994 & ND & $\begin{array}{l}\text { AM cortisol } \\
\text { UFC }\end{array}$ & $\begin{array}{l}<5 \mu \mathrm{g} / \mathrm{dL} \\
<990 \mu \mathrm{g} / \mathrm{d}\end{array}$ \\
\hline Bochicchio, 1995 & Within 6 mo & LD-DST & NI suppression \\
\hline Bakiri, 1996 & ND & $\begin{array}{c}\text { Circadian cortisol rhythm } \\
\text { LD-DST }\end{array}$ & $\begin{array}{l}\text { Normal } \\
\text { NI supression }\end{array}$ \\
\hline Sonino, 1996 & $5-15 d$ & $\begin{array}{l}\text { UFC } \\
\text { LD-DST }\end{array}$ & $\begin{array}{l}<248 \mathrm{nmol} / \mathrm{d} \\
\mathrm{NI} \text { suppression }\end{array}$ \\
\hline Blevins, 1998 & $6 \mathrm{mo}$ & $\begin{array}{l}\text { Cortisol or } \\
\text { UFC and } \\
\text { LD-DST }\end{array}$ & $\begin{aligned} & <5 \mu \mathrm{g} / \mathrm{dL} \\
& <15 \mu \mathrm{g} / \mathrm{d} \\
\text { NI } & \text { suppression }\end{aligned}$ \\
\hline Invitti, 1999 & ND & $\begin{array}{l}\text { UFC } \\
\text { AM Cortisol } \\
\text { AM ACTH }\end{array}$ & $\begin{array}{l}\text { Low/normal } \\
\text { Low/normal } \\
\text { Low/normal }\end{array}$ \\
\hline Swearingen, 1999 & $1-10 d$ & $\begin{array}{l}\text { AM Cortisol } \\
\text { UFC }\end{array}$ & $\begin{array}{l}<138 \mathrm{nmol} / \mathrm{L} \\
<55 \mathrm{nmol} / \mathrm{d}\end{array}$ \\
\hline Barbetta, 2001 & $1 \mathrm{~m}$ & $\begin{array}{l}\text { Cortisol } \\
\text { UFC }\end{array}$ & $\begin{array}{l}\text { Normal } \\
\text { Normal }\end{array}$ \\
\hline Chee, 2001 & $2 w k$ & $\begin{array}{l}\text { AM cortisol } \\
12 \text { AM cortisol } \\
\text { LD-DST }(2 \mathrm{mg}) \\
\quad \leq 5 \mathrm{ng} / \mathrm{L}\end{array}$ & $\begin{array}{c}\text { Normal } \\
<200 \mathrm{nmol} / \mathrm{L} \\
\text { Cortisol }<100 \mathrm{nmol} / \mathrm{L} \\
\text { ACTH }\end{array}$ \\
\hline Estrada, 2001 & $8-12 d$ & $\begin{array}{c}\text { Cortisol } 6 / 6 \text { h } 4 \mathrm{X} \\
\text { UFC }\end{array}$ & $\begin{array}{l}\text { Normal } \\
<331 \mathrm{nmol} / \mathrm{d}\end{array}$ \\
\hline Simmons, 2001 & $6 / 6$ h $3 d$ & Cortisol & $<275.9 \mathrm{nmol} / \mathrm{L}$ \\
\hline Rees, 2002 & $1-7 \mathrm{~d}$ & AM cortisol & $<50 \mathrm{nmol} / \mathrm{L}$ \\
\hline Shimon, 2002 & $4-6 w k$ & $\begin{array}{c}\text { UFC } \\
\text { LD-DST }(2 \mathrm{mg})\end{array}$ & $\begin{array}{l}\text { Normal } \\
<5 \mu \mathrm{g} / \mathrm{dL}\end{array}$ \\
\hline Yap, 2002 & $3-4 d$ & AM cortisol & $<50 \mathrm{nmol} / \mathrm{L}$ \\
\hline Chen, 2003 & $2 \mathrm{~d}$ & LD-DST $(1 \mathrm{mg})$ & $<8 \mu \mathrm{g} / \mathrm{dL}$ \\
\hline Pereira, 2003 & $6 \mathrm{mo}$ & $\begin{array}{l}\text { LD-DST }(1 \mathrm{mg}) \\
\quad \text { UFC } \times 2\end{array}$ & $\begin{array}{c}<100 \mathrm{nmol} / \mathrm{L} \\
\text { Normal }\end{array}$ \\
\hline Hammer, 2004 & $1 \mathrm{wk}$ & AM cortisol or & $\leq 5 \mu \mathrm{g} / \mathrm{dL}$ \\
\hline within $6 \mathrm{mo}$ & & $\begin{array}{c}\text { LD-DST }(1 \mathrm{mg}) \text { or } \\
\text { UFC }\end{array}$ & $\begin{array}{c}\leq 5 \mu \mathrm{g} / \mathrm{dL} \\
\text { Normal }\end{array}$ \\
\hline Rollin, 2004 & $1-12 d$ & Cortisol & $<5 \mu \mathrm{g} / \mathrm{dL}$ \\
\hline & & LD-DST & $<3 \mu \mathrm{g} / \mathrm{dL}$ \\
\hline Storr, 2005 & $1-8 d$ & Cortisol & $<50 \mathrm{nmol} / \mathrm{L}$ \\
\hline Atkinson, 2005 & $4-5 d$ & $\begin{array}{l}\text { AM cortisol } \\
\text { UFC } \\
\text { LD-DST ( } 2 \mathrm{mg})\end{array}$ & $\begin{array}{c}<300 \mathrm{nmol} / \mathrm{L} \\
\text { Normal } \\
\text { NI suppression }\end{array}$ \\
\hline Esposito, 2006 & $1-2 d$ & AM cortisol & $<140 \mathrm{nmol} / \mathrm{L}$ \\
\hline Acebes, 2007 & $24 \mathrm{~h}$ & $\begin{array}{l}\text { ACTH } \\
\text { Cortisol }\end{array}$ & $\begin{array}{l}<7.55 \mathrm{pmol} / \mathrm{L} \\
<585 \mathrm{nmol} / \mathrm{L}\end{array}$ \\
\hline
\end{tabular}

LD-DST: low-dose dexamethasone suppression test, UFC: urinary free cortisol, 17-OHCS: 17-hydroxy-corticosteroids, NI: normal

\# Cortisol $(\mathrm{nmol} / \mathrm{L})=$ cortisol $(\mu \mathrm{g} / \mathrm{dL}) \times 27.59$

* modified from Utz EL et al. (ref. 10) 
Table 4. Suggested biochemical criteria to define Cushing's disease cure/remission.

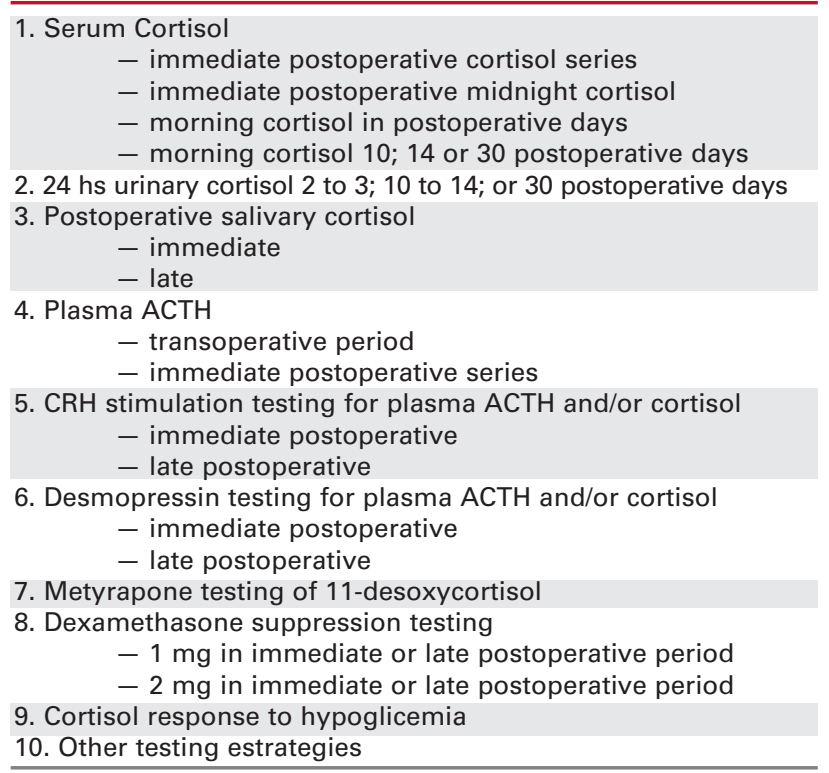

Estrada et al. reported $10 \%$ of relapse within 5 years and it may be higher with longer follow-ups (38). Pereira et al. showed recurrence in $14 \%$ of patients who have 2 - and 12 -week postoperative cortisol levels less than $50 \mathrm{nmol} / \mathrm{L}(1.8 \mu \mathrm{g} / \mathrm{dl})(25)$.

Thus, even when undetectable plasma cortisol levels are considered criteria of cure or remission (table 5 ), long-term relapse could still occur. In the early postoperative period (until 2 weeks after TSS), cortisol levels without glucocorticoid replacement less than 5 to 7 $\mu \mathrm{g} / \mathrm{dl}$ are associated with short- and medium-term CD remission, whereas cortisol concentration near this value should have more tests to better define remission status $(1,26)$. Some authors have suggested the terms "apparent cure" or "remission" to characterize individuals with postoperative undetectable cortisol levels or normal cortisol levels, respectively $(6,10)$.

\section{4-hour urinary cortisol}

Several authors have been using 24-h urinary cortisol measurement to assess immediate and long-term postoperative results in CD treatment $(18,20,22,25$, $30,38,41,50,54,57,58,60,63,67-69)$. Some of them considered normal urinary cortisol values enough to establish cure. In contrast, others suggest that lower cut off levels depending on assay techniques and additional tests should be considered to best determine cure. More recently, Urinary Free Cortisol (UFC) measurement was shown to have a diagnostic sensitivity and specificity of $100 \%$ and $98 \%$, respectively, in the differentiation of 48 patients with Cushing's syn- drome from 98 normal subjects and 95 obese individuals. However, although 24-h UFC measurement in 146 patients with Cushing's syndrome was shown to have a sensitivity of $95 \%$, it was noted that $11 \%$ had at least one out four 24 -h collections with values within the normal range (7). Furthermore, "raised" 24-h UFC levels have been documented in $40 \%$ of depressed inpatients and in 50\% of women with the polycystic ovarian syndrome. By definition, almost complete overlap in levels is seen in various causes of pseudo-Cushing's states, emphasizing the potential for diagnostic confusion (7). The problem of crossreactivity becomes a particular issue if the possibility of exogenous glucocorticoid administration exists (57). HPLC has recently been compared with RIA for the measurement of cortisol and cortisone in the assessment of endogenous Cushing's syndrome and Cushing's syndrome due to exogenous glucocorticoid ingestion. Since RIAs also suffer from problems of cross-reactivity, this approach may occasionally be useful in difficult cases where there is doubt about the origin of glucocorticoid (7-9). Cushing's syndrome is highly unlikely when several UFC collections are normal, once UFC estimations have a high sensitivity and low specificity (7).

\section{Low-dose dexamethasone cortisol suppression}

Low-dose dexamethasone cortisol suppression performed on days or weeks after surgery is used to predict cure or remission of CD. Bogan et al. suggested that "normal cortisol levels" in a 2-mg overnight dexamethasone test should be considered criteria for cure (52). Similarly, Fahlbusch et al. reported that levels less than $2 \mu \mathrm{g} / \mathrm{dl}$ are good predictors of cure (53). Other studies suggest that values of $<3 \mu \mathrm{g} / \mathrm{dl}(26),<$ $5 \mu \mathrm{g} / \mathrm{dl}(69),<100 \mathrm{nmol} / \mathrm{l}(25)$, or $<8 \mu \mathrm{g} / \mathrm{dl}(70)$ could better identify those patients on CD remission.

Drugs such as phenytoin, phenobarbitone, carbamezepine, and rifampicin will induce hepatic enzymatic clearance of dexamethasone, thereby reducing plasma dexamethasone concentration and resulting in false-positive responses to dexamethasone suppression test $(2,6,7,9)$. Estrogens increase cortisol-binding globulin concentration in the circulation, causing false-positive tests in about $50 \%$ of women on the oral contraceptive pill when RIA tests are used. It is our routine practice, when possible and particularly in mild cases, the estrogen-containing drugs are interrupted and investigation delayed for 6 weeks to allow cortisol-binding globulin to return to baseline $(2,9)$. 
Table 5. Cushing's disease remission, relapse, and glucocorticoid replacement in literature series with postoperative cortisol cutoff values $<50 \mathrm{nmol} / \mathrm{L}(<1.8 \mu \mathrm{g} / \mathrm{dL})$.

\begin{tabular}{lcccc}
\hline Autor & N & $\begin{array}{c}\text { Remission } \\
(\%)\end{array}$ & $\begin{array}{c}\text { Relapse } \\
\text { (\%) }\end{array}$ & $\begin{array}{c}\text { GC in PO } \\
\text { (days) }\end{array}$ \\
Trainer, 1993 & 48 & 42 & 0 & - \\
McCance, 1993 & 41 & 48 & 0 & - \\
Bochichio, 1995 & 94 & - & 4 & $\mathrm{~ns}$ \\
Newell-Price, 1997 & 103 & 48 & 0 & - \\
Estrada, 2001 & 58 & $\mathrm{~ns}$ & 3.4 & $7-12$ \\
Yap, 2001 & 97 & 68.5 & 11.5 & $1-2$ \\
Rees, 2001 & 54 & 77 & 5 & $<7$ \\
Pereira, 2003 & 80 & 48 & 15.7 & $>6$ \\
Storr, 2005 & 27 & 59 & 0 & $>1$ \\
\hline
\end{tabular}

\section{ACTH}

Fahlbusch and Buchfelder (53) investigated perioperative ACTH levels measured 5-6 days after surgery. All 47 patients with a postoperative reduction of serum ACTH to low levels $(<10 \mathrm{ng} / \mathrm{L}$ or $<2,2$ $\mathrm{pmol} / \mathrm{L}$ ) had clinical remission, compared to only 13 out of 21 patients with a moderate decrease and only one out of 15 with ACTH $>50 \mathrm{ng} / \mathrm{L}(>11 \mathrm{pmol} / \mathrm{L})$, and had normal suppression of serum cortisol after 2 mg dexamethasone administration.

Invitti et al. (18) suggested that there is a direct correlation between ACTH levels and prediction of relapse. Czirjak et al. (71) used chemiluminescence assay to measure plasma ACTH in the intraoperative period, immediately after adenomectomy and subsequently in the following 2 and $24 \mathrm{~h}$. Those samplings were then compared to cortisol plasma levels collected between 7 and 10 days post surgery. Seven patients were followed by a long period of time. This study showed wide variability in first plasma ACTH sample with a significant decrease level after 2 and 24 h to normal or even below normal range in cured patients. Similar data were observed by other authors $(72,73)$.

The major limitation of this approach is technical details of ACTH measurement. To be accurate, ACTH samples need to be collected and handled at low temperatures, and appropriately stored. In this setting, it constitutes a complex method to be implemented as routine in intraoperative period to monitor response to therapy (2).

\section{Corticotropin-releasing hormone stimulation testing}

In the majority of patients with $\mathrm{CD}$, the intravenous administration of corticotropin-releasing hormone $(\mathrm{CRH})$ causes an excessive rise in plasma ACTH and cortisol and this pattern remains in patients who have
Table 6. Relapse related features observed by The European Cushing's Disease Survey Study Group ( $n=668$; remission= 76\%) [ref. 35].

\begin{tabular}{lc} 
1. Cortisol postoperative $(p<0.0001)$ & Relapse \\
Undetectable & $4.3 \%$ \\
Normal "high" & $26.3 \%$ \\
2. Cortisol response to CRH $(p<0.01)$ & $17.5 \%$ \\
Normal & $42.9 \%$ \\
Extremely high & $0 \%$ \\
Absent & $3 \%$ \\
3. Glucocorticoid dependence $(p<0.0001)$ & $24 \%$ \\
More than 1 year & $47 \%$ \\
Less than 1 year & \\
Absent & \\
\hline
\end{tabular}

residual tumor or are prone to relapse $(5,10)$. Avgerinos et al. demonstrated no relapse in 23 patients who showed a decrease response to CRH test in a followup period of 6 to 42 months after TSS. In contrast, 3 of 6 who responded normally to the test had relapsed (75). Several studies have shown similar results (1618,76,77), although CRH test was not performed at the same moment in each study.

\section{Desmopressin testing}

Colombo et al. demonstrated that cortisol response to desmopressin infusion could identify patients with an increased incidence of relapse (78). In this study, the authors showed that persistence of response of cortisol and ACTH to desmopressin test after TSS could happen even when clinical and hormonal factors had improved. In 2000, Colombo et al., comparing desmopressin test $(10 \mu \mathrm{g}$ IV) with CRH test $(1 \mu \mathrm{g} / \mathrm{kg})$ response in 34 patients before and after TSS, showed that 10 patients considered in remission after a period of 1 to 36 months never responded to desmopressin test. Conversely, 5 patients that normalized plasma basal cortisol but still responded to desmopressin test presented relapse after 12 to $24 \mathrm{hr}$ after surgery. Ten patients were assessed several years after TSS, six of them were in remission and showed normal response to $\mathrm{CRH}$ test and no response to desmopressin test. The other 4 patients presented discrepant results but all of them had been submitted to radiotherapy, which could be a confusing factor (79). Other study reported CD patients that responded to desmopressin test before TSS but presented no response after hypercortisolism resolution, but responded once again, showing disease relapse prediction (80). Additionally, other studies suggested that desmopressin test should be part of diagnostic and follow up of patients with CD as a useful test to determine cure and remission $(81,82)$. 


\section{Metyrapone testing}

Van Aken et al., retrospectively, studied 29 of 77 patients submitted to TSS and followed for more than 11 months. Initial evaluation consisted of 24-h urinary cortisol, basal plasma cortisol, and metyrapone testing with 11-deoxycortisol sample collection, 14 days after TSS procedure. Hydrocortisone was withdrawn one day before the test in patients that were receiving reposition. Patients that presented basal cortisol less than 140 nmol/1 and 24-h urinary cortisol less than $250 \mathrm{nmol} / \mathrm{l}$ were considered cured. After 6 months of glucocorticoid dependence, patients were submitted to low-dose dexamethasone test. Remission was considered when plasma cortisol was less than $140 \mathrm{nmol} / \mathrm{l}$ and 24-h urinary cortisol was in the normal range. Seventeen of 29 patients were in remission of $\mathrm{CD}$, although 3 of them presented relapse after 17, 32, and 80 months from TSS. In this series, metyrapone test showed a sensibility of $100 \%$ and a specificity of $75 \%$ in detection of $C D$ relapse. 11deoxycortisol levels above $150 \mathrm{nmol} / \mathrm{l}$ were considered as a prognostic factor (83).

\section{Other testing strategies}

Lack of circadian cortisol secretion and no response to hypoglycemia after initial hypocortisolemic phase predict relapse $(38,84)$. Inadequate suppression of cortisol and ACTH levels after loperamide, an opioid agonist, has been associated with CD relapse (77). Pieters et al. reported a paradoxical preoperative increase (> $160 \mathrm{nmol} / \mathrm{L}$ ) of serum cortisol to TRH or LHRH (1 of 16 cures vs. 6 of 11 failures) that was also associated with lower chance of cure (15).

\section{ASSOCIATION OF SEVERAL TESTING AND FEATURES}

Bochicchio, Losa, and Buchfelder, when published data from The European Cushing's Disease Survey Study Group, reported that CD remission was observed in 510 $(76.3 \%)$ out of 668 patients from several centers (35). Adenoma identification by image or during surgery was associated with good prognosis. Relapsed occurred in 65 patients (12.7\%) during a median follow-up of 39.3 months ( 6 to 104 months). There was no correlation of relapse and time after surgery procedure. Low cortisol levels, lack of response in CRH testing, and the need for long-term glucocorticoid replacement therapy were associated with low risk of relapse. It is inversely related to the risk of relapse in 5 years: replacement greater than 1 year $=$ relapse risk of $3 \%$; less than 1 year $=24 \%$, and no replacement $=47 \%(35)$.

\section{SUMMARY}

In Cushing's disease appropriate classification of postoperative outcome is dependent on biochemical assessment of endogenous cortisol production. Although there is no consensus, factors such as adenoma identification during surgery or in histology, adenoma size, severe hypoadrenalism following adenoma resection, lack of response to desmopressin and CRH tests, exogenous steroid replacement for more than 6 months, return of the diurnal pattern of cortisol secretion, normal cortisol response to low-dose dexamethasone test are acceptable CD cure or remission features. Even in patients with undetectable cortisol levels immediately after surgery, long-term follow up is necessary, since 5 to $15 \%$ of patients could have future relapse. Recently, salivary cortisol at midnight seems to be particularly useful for periodic disease status evaluation. Cortisol dynamics after TSS resection for CD can present several patterns. Therefore, a postoperative approach that combines several tests at regular followup intervals is the best choice to guide the need for future intervention. In this context, for the information of patients, it is important to define the appropriated classification term of CD outcome. We suggest "remission" opposed to "cure", recognizing that long-term follow-up is essential to detect disease relapse.

Therefore, patients with CD should have longterm indeterminate monitoring of the CRH-ACTH-cortisol axis and associated morbidities, especially hypopituitarism, diabetes mellitus, hypertension, cardiovascular disturbances, and osteoporosis.

\section{ACKNOWLEDGMENTS}

We are indebted to Prof. Luis H. Canani for critical evaluation of this manuscript.

\section{REFERENCES}

1. Czepielewski MA, Rollin GAFS. Tratamento da Síndrome de Cushing. In: Vilar L (ed). Endocrinologia Clínica. Rio de Janeiro: Guanabara Koogan, 2006. pp. 418-35.

2. Rollin GAFS, Copstein E, Czepielewski MA. Síndrome de Cushing. In: Gross JL, Silveiro SP (eds). Rotinas Diagnósticas em Endocrinologia. Porto Alegre: ArtMed, 2004. pp. 153-8.

3. Vilar L, Coelho CE. Diagnóstico e diagnóstico diferencial da Síndrome de Cushing. In: Vilar L (ed). Endocrinologia Clínica. Rio de Janeiro: Guanabara Koogan, 2006. pp. 397-417.

4. Vilar L, Naves LA, Freitas MC, Moura E, Canadas V, Leal E, et al. Endogenous Cushing's syndrome: Clinical and laboratorial features in 73 cases. Arq Bras Endocrinol Metab 2007;51(4):566-74. 
5. Arnaldi $G$, Angeli $A$, Atkinson AB, Bertagna $X$, Cavagnini $F$, Chrousos GP, et al. Diagnosis and complications of Cushing's syndrome: A consensus statement. J Clin Endocrinol Metab 2003:88(12):5593-602.

6. Bertagna X, Raux-Demay MC, Giulhaume B, Girard F, Luton JP. Cushing's disease. In: Melmed S (ed). The Pituitary. $2^{\text {nd }}$ ed. Malden: Blackwell, 2002. pp. 592-612.

7. Newell-Price J, Trainer P, Besser GM, Grossman AB. The diagnosis and differential diagnosis of Cushing's syndrome and pseudo-Cushing's states. Endocr Rev 1998;19:647-72.

8. Nieman LK, Ilias I. Evaluation and treatment of Cushing's syndrome. Am J Med 2005;118(12):1340-6.

9. Findling JW, Raff H. Cushing's syndrome: Important issues in diagnosis and management. J Clin Endocrinol Metab 2006;91(10):3746-53.

10. Utz AL, Swearingen B, Biller BMK. Pituitary surgery and postoperative management in Cushing's disease. Endocrinol Metab Clin North Am 2005;34:459-78.

11. Fitzgerald PA, Aron DC, Findling JW, Brooks RM, Wilson CB, Forsham PH, et al. Cushing's disease: Transient secondary adrenal insufficiency after selective removal of pituitary microadenomas; evidence for a pituitary origin. J Clin Endocrinol Metab 1982;54:413-22.

12. Timmers HJ, Van Ginneken EM, Wesseling P, Sweep CG, Hermus AR. A patient with recurrent hypercortisolism after removal of an ACTH-secreting pituitary adenoma due to an adrenal macronodule. J Endocrinol Invest 2006;29 (10):934-9.

13. Udelsman R, Norton JA, Jelenich SE, Goldstein DS, Linehan WM, Loriaux DL, et al. Responses of the hypothalamic-pituitary-adrenal and renin-angiotensin axes and the sympathetic system during controlled surgical and anesthetic stress. J Clin Endocrinol Metab. 1987;64(5):986-94.

14. Pimentel-Filho FR. Dinâmica hipófise-adrenal durante cirurgia tranesfenoidal. In: Liberman B, Cukiert A. (eds). Neuroendocrinologia Clínica e Cirúrgica. São Paulo: Lemos Editorial, 2002. pp. 507-15.

15. Pieters GF, Hermus AR, Meijer E, Smals AG, Kloppenborg PW. Predictive factors for initial cure and relapse rate after pituitary surgery for Cushing's disease. J Clin Endocrinol Metab 1989;69(6):1122-6.

16. Nishizawa S, Oki Y, Ohta S, Yokota N, Yokoyama T, Uemura $\mathrm{K}$. What can predict postoperative "endocrinological cure" in Cushing's disease? Neurosurgery 1999;45(2):239-44.

17. Newell-Price J. Transsphenoidal surgery for Cushing's disease: Defining cure and following outcome. Clin Endocrinol (Oxf) 2002;56:19-21.

18. Invitti C, Pecori Giraldi F, de Martin M, Cavagnini F. Diagnosis and management of Cushing's syndrome: Results of an Italian multicentre study. Study Group of the Italian Society of Endocrinology on the Pathophysiology of the Hypothalamic-Pituitary-Adrenal Axis. J Clin Endocrinol Metab 1999;84(2):440-8.

19. George DH, Scheithauer BW, Kovacs K, Horvath E, Young WF $\mathrm{Jr}$, Lloyd RV, et al. Crooke's cell adenoma of the pituitary: An aggressive variant of corticotroph adenoma. Am J Surg Pathol 2003;27(10):1330-6.

20. Sonino N, Zielezny M, Fava GA, Fallo F, Boscaro M. Risk factors and long-term outcome in pituitary-dependent Cushing's disease. J Clin Endocrinol Metab 1996;81(7):2647-52.

21. Robert F, Hardy J. Cushing's disease: A correlation of radiological, surgical and pathological findings with therapeutic results. Pathol Res Pract 1991;187:617-21.

22. Blevins LS Jr, Christy JH, Khajavi M, Tindall GT. Outcomes of therapy for Cushing's disease due to adrenocorticotropinsecreting pituitary macroadenomas. J Clin Endocrinol Metab 1998;83:63-7.

23. Mampalam TJ, Tyrell B, Wilson CB. Transsphenoidal microsurgery for Cushing's disease. Ann Int Med 1988;109:487-93.

24. Cannavo S, Almoto B, Dall'Asta C, Corsello S, Lovicu RM, De Menis $\mathrm{E}$, et al. Long-term results of treatment in patients with ACTH-secreting pituitary macroadenomas. Eur J Endocrinol 2003;149(3):195-200.
25. Pereira AM, van Aken MO, van Dulken $H$, Schutte PJ, Biermasz NR, Smit JW, et al. Long-term predictive value of postsurgical cortisol concentrations for cure and risk of recurrence in Cushing's disease. J Clin Endocrinol Metab 2003;88(12):5858-64.

26. Rollin GA, Ferreira NP, Junges M, Gross JL, Czepielewski MA. Dynamics of serum cortisol levels after transsphenoidal surgery in a cohort of patients with Cushing's disease. J Clin Endocrinol Metab 2004;89(3):1131-9.

27. Oldfield EH, Chrousos GP, Schulte HM, Schaaf M, McKeever $P E$, Krudy $A G$, et al. Preoperative lateralization of ACTHsecreting pituitary microadenomas by bilateral and simultaneous inferior petrosal venous sinus sampling. N Engl J Med 1985;312:100-3.

28. Pecori-Giraldi F, Moro M, Cavagnini F. Gender-related differences in the presentation and course of Cushing's disease. $\mathbf{J}$ Clin Endocrinol Metab 2003;88(4):1554-8.

29. Netea-Maier RT, van Lindert EJ, den Heijer M, van der Eerden A, Pieters GF, Sweep CG, et al. Transsphenoidal pituitary surgery via the endoscopic technique: Results in 35 consecutive patients with Cushing's disease. Eur J Endocrinol 2006;154(5):675-84.

30. Guilhaume B, Bertagna X, Thomsen M, Bricaire C, Vila-Porcile $E$, Olivier $L$, et al. Transsphenoidal pituitary surgery for the treatment of Cushing's disease: Results in 64 patients and long term follow-up studies. J Clin Endocrinol Metab 1988;66(5):1056-64.

31. Barker FGN, Klibanski A, Swearingen B. Transsphenoidal surgery for pituitary tumors in United States, 1996-2000: Mortality, morbidity, and the effects of hospital and surgeon volume. J Clin Endocrinol Metab 2003;88:4709-19.

32. Katznelson L, Bogan JS, Trob JR, Schoenfeld DA, HedleyWhyte ET, Hsu DW, et al. Biochemical assessment of Cushing's disease in patients with corticotroph macroadenomas. J Clin Endocrinol Metab 1998;83(5):1619-23.

33. Trainer PJ, Lawrie HS, Verhelst J, Howlett TA, Lowe DG, Grossman AB, et al. Transsphenoidal resection in Cushing's disease: Undetectable serum cortisol as the definition of successful treatment. Clin Endocrinol (Oxf) 1993:38(1):73-8.

34. Rees DA, Hanna FW, Davies JS, Mills RG, Vafidis J, Scanlon MF. Long-term follow-up results of transsphenoidal surgery for Cushing's disease in a single centre using strict criteria for remission. Clin Endocrinol (Oxf) 2002;56(4):541-51.

35. Bochicchio D, Losa M, Buchfelder M. Factors influencing the immediate and late outcome of Cushing's disease treated by transsphenoidal surgery: A retrospective study by the European Cushing's Disease Survey Group. J Clin Endocrinol Metab 1995;80(11):3114-20.

36. Acebes JJ, Martino J, Masuet C, Montanya E, Soler J. Early post-operative ACTH and cortisol as predictors of remission in Cushing's disease. Acta Neurochir (Wien) 2007; 149(5):471-7.

37. Devoe DJ, Miller WL, Conte FA, Kaplan SL, Grumbach MM, Rosenthal SM, et al. Long-term outcome in children and adolescents after transsphenoidal surgery for Cushing's disease. J Clin Endocrinol Metab 1997;82(10):3196-202.

38. Estrada J, Garcia-Uria J, Lamas C, Alfaro J, Lucas T, Diez S, et al. The complete normalization of the adrenocortical function as the criterion of cure after transsphenoidal surgery for Cushing's disease. J Clin Endocrinol Metab 2001;86 (12):5695-9.

39. Yap LB, Turner HE, Adams CB, Wass JA. Undetectable postoperative cortisol does not always predict long-term remission in Cushing's disease: A single centre audit. Clin Endocrinol (Oxf) 2002;56(1):25-31.

40. Storr HL, Afshar F, Matson M, Sabin I, Davies KM, Evanson J, et al. Factors influencing cure by transsphenoidal selective adenomectomy in paediatric Cushing's disease. Eur J Endocrinol. 2005;152(6):825-33.

41. Burke CW, Adams CB, Esiri MM, Morris C, Bevan JS. Transsphenoidal surgery for Cushing's disease: does what is removed determine the endocrine outcome? Clin Endocrinol (Oxf) 1990;33(4):525-37. 
42. Savage MO, Storr HL, Chan LF, Grossman AB. Diagnosis and treatment of pediatric Cushing's disease. Pituitary 2007; [Epub ahead of print].

43. Lindsay JR, Nansel T, Baid S, Gumowski J, Nieman LK. Longterm impaired quality of life in Cushing's syndrome despite initial improvement after surgical remission. J Clin Endocrinol Metab 2006;91(2):447-53.

44. Colao A, Pivonello R, Spiezia S, Faggiano A, Ferone D, Filippella $M$, et al. Persistence of increased cardiovascular risk in patients with Cushing's disease after five years of successful cure. J Clin Endocrinol Metab 1999;84:2664-72.

45. Forget $H$, Lacroix $A$, Cohen $H$. Persistent cognitive impairment following surgical treatment of Cushing's syndrome. Psychoneuroendocrinology 2002;27:376-83.

46. van Aken MO, Pereira AM, Biermasz NR, van Thiel SW, Hoftijzer HC, Smit JW, et al. Quality of life in patients after longterm biochemical cure of Cushing's disease. J Clin Endocrinol Metab 2005;90(6):3279-86.

47. Simmons NE, Alden TD, Thorner MO, Laws ER Jr. Serum cortisol response to transsphenoidal surgery for Cushing disease. J Neurosurg 2001;95(1):1-8.

48. Esposito F, Dusick JR, Cohan P, Moftakhar P, McArthur D, Wang $C$, et al. Clinical review: Early morning cortisol levels as a predictor of remission after transsphenoidal surgery for Cushing's disease. J Clin Endocrinol Metab 2006:91(1):7-13.

49. Toms GC, McCarthy MI, Niven MJ, Orteu CH, King TT, Monson JP. Predicting relapse after transsphenoidal surgery for Cushing's disease. J Clin Endocrinol Metab 1993;76 (2):291-4.

50. McCance DR, Gordon DS, Fannin TF, Hadden DR, Kennedy L, Sheridan B, et al. Assessment of endocrine function after transsphenoidal surgery for Cushing's disease. Clin Endocrinol (Oxf) 1993;38(1):79-86.

51. Graham KE, Samuels MH, Raff H, Barnwell SL, Cook DM. Intraoperative adrenocorticotropin levels during transsphenoidal surgery for Cushing's disease do not predict cure. J Clin Endocrinol Metab 1997;82(6):1776-9.

52. Boggan JE, Tyrrell JB, Wilson CB. Transsphenoidal microsurgical management of Cushing's disease. Report of 100 cases. J Neurosurg 1983;59(2):195-200.

53. Fahlbusch $R$, Buchfelder M, Muller OA. Transsphenoidal surgery for Cushing's disease. J R Soc Med 1986;79(5):2629.

54. Chandler WF, Schteingart DE, Lloyd RV, McKeever PE, IbarraPerez G. Surgical treatment of Cushing's disease. J Neurosurg 1987;66(2):204-12.

55. Nakane T, Kuwayama A, Watanabe M, Takahashi T, Kato T, Ichihara $\mathrm{K}$, et al. Long term results of transsphenoidal adenomectomy in patients with Cushing's disease. Neurosurgery $1987 ; 21(2): 218-22$.

56. Schrell U, Fahlbusch R, Buchfelder M, Riedl S, Stalla GK, Muller OA. Corticotropin-releasing hormone stimulation test before and after transsphenoidal selective microadenomectomy in 30 patients with Cushing's disease. J Clin Endocrinol Metab 1987;64(6):1150-9.

57. Arnott RD, Pestell RG, McKelvie PA, Henderson JK, McNeill PM, Alford FP. A critical evaluation of transsphenoidal pituitary surgery in the treatment of Cushing's disease: Prediction of outcome. Acta Endocrinol (Copenh) 1990;123 (4):423-30.

58. Tindall GT, Herring CJ, Clark RV, Adams DA, Watts NB. Cushing's disease: Results of transsphenoidal microsurgery with emphasis on surgical failures. J Neurosurg 1990;72 (3):363-9.

59. Ludecke DK. Transnasal microsurgery of Cushing's disease 1990. Overview including personal experiences with 256 patients. Pathol Res Pract 1991;187(5):608-12.

60. Lindholm J. Endocrine function in patients with Cushing's disease before and after treatment. Clin Endocrinol (Oxf) 1992;36(2):151-9.

61. Ram Z, Nieman LK, Cutler GB Jr, Chrousos GP, Doppman JL, Oldfield EH. Early repeat surgery for persistent Cushing's disease. J Neurosurg 1994;80(1):37-45.
62. Bakiri F, Tatai S, Aouali R, Semrouni M, Derome P, Chitour F, et al. Treatment of Cushing's disease by transsphenoidal, pituitary microsurgery: Prognosis factors and long-term follow-up. J Endocrinol Invest 1996;19(9):572-80.

63. Swearingen B, Biller BM, Barker FG 2nd, Katznelson L, Grinspoon S, Klibanski A, et al. Long-term mortality after transsphenoidal surgery for Cushing disease. Ann Intern Med 1999;130(10):821-4.

64. Buchfelder M, Fahlbusch R, Wentzlaff-Eggebert H, Brabant G, Stalla GK, Muller OA. Does an analysis of the pulsatile secretion pattern of adrenocorticotropin and cortisol predict the result of transsphenoidal surgery in Cushing's disease? J Clin Endocrinol Metab 1993;77(3):720-4.

65. Chee GH, Mathias DB, James RA, Kendall-Taylor P. Transsphenoidal pituitary surgery in Cushing's disease: Can we predict outcome? Clin Endocrinol (Oxf) 2001;54(5):617-26.

66. Imaki T, Tsushima T, Hizuka N, Odagiri E, Murata Y, Suda T, et al. Postoperative plasma cortisol levels predict long-term outcome in patients with Cushing's disease and determine which patients should be treated with pituitary irradiation after surgery. Endocr J 2001;48(1):53-62.

67. Shimon I, Ram Z, Cohen ZR, Hadani M. Transsphenoidal surgery for Cushing's disease: Endocrinological follow-up monitoring of 82 patients. Neurosurgery 2002;51(1):57-61; discussion 61-2.

68. Atkinson AB, Kennedy A, Wiggam MI, McCance DR, Sheridan B. Long-term remission rates after pituitary surgery for Cushing's disease: The need for long-term surveillance. Clin Endocrinol (Oxf) 2005;63(5):549-59.

69. Hammer GD, Tyrrell JB, Lamborn KR, Applebury CB, Hannegan ET, Bell $S$, et al. Transsphenoidal microsurgery for Cushing's disease: Initial outcome and long-term results. J Clin Endocrinol Metab 2004;89(12):6348-57.

70. Chen JC, Amar AP, Choi S, Singer P, Couldwell WT, Weiss $\mathrm{MH}$. Transsphenoidal microsurgical treatment of Cushing disease: Postoperative assessment of surgical efficacy by application of an overnight low-dose dexamethasone suppression test. J Neurosurg 2003;98(5):967-73.

71. Czirjak S, Bezzegh A, Gal A, Racz K. Intra- and postoperative plasma ACTH concentrations in patients with Cushing's disease cured by transsphenoidal pituitary surgery. Acta Neurochir (Wien) 2002;144(10):971-7.

72. Flitsch J, Knappe UJ, Ludecke DK. The use of postoperative ACTH levels as a marker for successful transsphenoidal microsurgery in Cushing's disease. Zentralbl Neurochir 2003;64(1):6-11.

73. Pimentel-Filho FR, Cukiert A, Miyashita F, Huayllas MK, Knoepfelmacher M, Salgado LR, et al. Adrenocorticotropin levels do not change during early recovery of transsphenoidal surgery for ACTH-secreting pituitary tumors. J Endocrinol Invest 2001;24(2):83-7.

74. Pimentel-Filho FR, Silva ME, Nogueira KC, Berger K, Cukiert A, Liberman B. Pituitary-adrenal dynamics after ACTH-secreting pituitary tumor resection in patients receiving no steroids post-operatively. J Endocrinol Invest 2005;28(6):502-8.

75. Avgerinos PC, Chrousos GP, Nieman LK, Oldfield EH, Loriaux $\mathrm{DL}$, Cutler GB Jr. The corticotropin-releasing hormone test in the postoperative evaluation of patients with Cushing's syndrome. J Clin Endocrinol Metab 1987;65(5):906-13.

76. Vignati F, Berselli ME, Loi P. Early postoperative evaluation in patients with Cushing's disease: Usefulness of ovine corticotropin-releasing hormone test in the prediction of recurrence of disease. Eur J Endocrinol 1994;130(3):235-41.

77. Barbetta L, Dall'Asta C, Tomei G, Locatelli M, Giovanelli M, Ambrosi B. Assessment of cure and recurrence after pituitary surgery for Cushing's disease. Acta Neurochir (Wien) 2001;143(5):477-81; discussion 481-2.

78. Colombo P, Passini E, Re T, Faglia G, Ambrosi B. Effect of desmopressin on ACTH and cortisol secretion in states of ACTH excess. Clin Endocrinol (Oxf) 1997;46(6):661-8.

79. Colombo P, Dall'Asta C, Barbetta L, Re T, Passini E, Faglia G, et al. Usefulness of the desmopressin test in the postoperative evaluation of patients with Cushing's disease. Eur $\mathbf{J}$ Endocrinol 2000;143(2):227-34. 
80. Dall'Asta C, Barbetta L, Bonavina L, Beck-Peccoz P, Ambrosi $B$. Recurrence of Cushing's disease preceded by the reappearance of ACTH and cortisol responses to desmopressin test. Pituitary 2004:7(3):183-8.

81. Losa M, Mortini P, Dylgjeri S, Barzaghi R, Franzin A, Mandelli $C$, et al. Desmopressin stimulation test before and after pituitary surgery in patients with Cushing's disease. Clin Endocrinol (Oxf) 2001;55(1):61-8.

82. Valero R, Vallette-Kasic S, Conte-Devolx B, Jaquet $P$, Brue $T$. The desmopressin test as a predictive factor of outcome after pituitary surgery for Cushing's disease. Eur J Endocrinol 2004:151(6):727-33

83. Van Aken MO, de Herder WW, van der Lely AJ, de Jong FH, Lamberts SW. Postoperative metyrapone test in the early assessment of outcome of pituitary surgery for Cushing's disease. Clin Endocrinol (Oxf) 1997;47(2):145-9.
84. Veldman RG, Frolich M, Pincus SM, Veldhuis JD, Roelfsema F. Apparently complete restoration of normal daily adrenocorticotropin, cortisol, growth hormone, and prolactin secretory dynamics in adults with Cushing's disease after clinically successful transsphenoidal adenomectomy. J Clin Endocrinol Metab 2000;85(11):4039-46.

Address for correspondence:

Mauro A. Czepielewski

Division of Endocrinology

Hospital de Clínicas de Porto Alegre, UFRGS

Ramiro Barcelos 2400, prédio 14, 4 andar

90035-003 Porto Alegre, RS

Fax: (51) 2101-8127

E-mail: maurocze@terra.com.br 